\title{
Queenship in the Mediterranean: Negotiating the Role of the Queen in the Medieval and Early Modern Eras
}

Review Number: 1676

Publish date: Thursday, 23 October, 2014

Author: Elena Woodacre

ISBN: 9781137362827

Date of Publication: 2013

Price: $£ 62.00$

Pages: 288pp.

Publisher: Palgrave Macmillan

Publisher url: http://www.palgrave.com/page/detail/queenship-in-the-mediterranean-elena-woodacre/?K=97811373

Place of Publication: Basingstoke

Reviewer: Estelle Paranque

In the recent years, queenship has interested and fascinated numerous scholars.(1) While some queens, notably British and French ones, have already received interest from historians, this study is keen on shedding light on the female rulers of the Mediterranean. From Sicily to Aragon, the chapters of this collection focus on queen consorts, regents, and sometimes regnant who have influenced in different ways the history of their realms and played an important role in the public sphere as well as on the political scene. Through chronicles, manuscripts, letters, and other sorts of primary sources, the authors reveal the political roles of the queens and as Elena Woodacre explains 'how these women spread the culture of the Mediterranean northwards through their marital and familial connections' (p. 1). Set up chronologically, the edited collection starts with the medieval era and ends with the 18th century.

The collection consists of an introduction and 13 chapters. Chapter two introduces the idea of powerful women ruling over the Mediterranean well. Alexandra Karagianni chooses to focus mostly on three empresses that ruled, at times alone, the Byzantine Empire. The author starts her essay with an explanation of the difficulties for women of living in a male-dominated society and focuses on their actual rights in such a society (p. 9). She then examines the reigns of the three empresses. Her research is mostly based on chronicles and secondary sources which deal more broadly with the Byzantine Empire. Her chapter encourages the interest that people should have in Byzantine empresses and reveals the importance of their roles and reigns, and to some extent their successes, in a patriarchal society (p. 23).

Chapter three examines the power and authority that Joanna, Queen of Sicily (1177-89) gained during her lifetime. Through varied and well-analysed primary sources, Colette Bowie follows Joanna's life through important political events. Her essay reveals as much the personal difficulties as the political ones that Joanna encountered and questions how a princess from such a powerful family (she was a Plantagenet, the daughter of Henry II of England and Eleanor of Aquitaine) could have had so little power and authority as queen consort and have finished her life as a nun (p. 40). With her essay, Colette Bowie points out the difficulties for a princess in actually being a successful monarch, indicating that coming from a powerful family was sometimes just not enough. 
In the next chapter, Melissa R. Katz studies the little-known figure: Violante de Aragon and specifically looks at her years as a widow and its impact on her access to power. Through two important newly found manuscripts which constitute Violante's will (p. 52), Katz sheds light on the dowager's links and reevaluates her relationship with her family and her children. The author also reveals Violante's willingness to distance herself from any succession decisions (p. 59) and that she preferred 'seeking power and influence in a more welcoming arena' (p. 60). This essay highlights the struggles of Violante and also re-evaluates her whole reputation.

The approach of the following essay by Maria Proctor-Tiffany is original, relying on material culture, which is all-too-often ignored when it comes to analysing a monarch's life. This chapter focuses on the reign and life of a medieval queen named Clémence of Hungary through her '99-page inventory' which 'describes more than 1,000 objects that belonged to the queen' (p. 74). In revealing the objects and belongings of the medieval queen, the author endeavours to highlight Clémence of Hungary's role and importance during her lifetime and after. Proctor-Tiffany is also interested in demonstrating the importance of material culture in understanding the political value and status of monarchs (p. 89).

Chapter six sheds light on the life, reign and representation of the Portuguese medieval queen Leonor Teles. Isabel de Pina Baleiras re-evaluates Teles' reputation and importance in the events that occurred during her lifetime. With a very well-structured argument, the thorough use of primary sources, and an engaging writing style, the author manages to question the existent historiography of the Portuguese queen and to explain the complexity of her status as well as the events that happened to her: the death of her husband King Fernando I of Portugal (p. 105), the abdication to her son-in-law Juan I of Castile (p. 107), her exile (p. 108), and the growing reputation of her as a 'bad woman' (p. 112). While it is plausible to discuss Leonor Teles' reputation, one fact remains: she was regent of Portugal for three months and acted as king thanks to her husband's desire to see her ruling after him. This 'faith' in his wife's ability to rule also demonstrates to some extent the kind of dynamic that some royal couples might have had at a time when the patriarchal society dominated.

With a very good grasp and understanding of the sources used, Ana Rodrigues Oliveira is interested in the life and representation of Philippa of Lancaster, who became queen of Portugal in 1387. Through the praise the queen received, and the focus on her good qualities, such as being 'a loving wife and mother, well educated, guided by Christian values, deeply pious' (p. 134), the author examines the chronicles that have provided an extremely positive portrait of Philippa. While the chroniclers portrayed Philippa as what we might call a good queen, the author also reveals that they often dismissed her political activity in order to pursue this image of a pious woman (p. 138). They also compared her to Leonor Teles who had a far less reputable name as discussed in the previous chapter (p. 140). In all, Ana Rodrigues Oliveira sheds light on the complexity and the reasons for the creation of a good or bad reputation and how queens were perceived in medieval Portugal.

In chapter eight, Zita Rohr examines how the court culture of Aragon and France were embodied in Yolande of Aragon when she became French queen consort. Interested in the different cultures, the author discusses Yolande's queenship and her political strategies and influences. Through her reign and later on her son's, René of Anjou, both Aragonese and French court cultures 'were enriched in equal measure' (p. 159) allowing us to see the kind of difference a queen could make not only in terms of political decisions but also in terms of cultural influence. 
With an interesting study of the chronicles of the period, Diana Pelaz Flores points out the important role played by the queen consort in Castile at the beginning of the 15th century (p. 167). Juan II of Castile reigned during 48 years, and was married twice. The ninth chapter of this collection demonstrates the different political roles that his two wives, and therefore queen consorts, played in the political sphere of the Castilian society. Maria of Aragon and later Isabel of Portugal proved to have their own political agendas and knew how to assert their own authority when necessary.

Chapter ten sheds light on the life of a princess who was first lady of her kingdom and who, according to Manuela Santos Silva, seemed to enjoy this status (p. 200). In depicting Isabel of Portugal's life before her queenship, the author depicts the different political events that had an impact on Isabel's idea of authority and power. At her mother's death and with the war impending, her father, king Joao I gave her various 'territories' (p. 196). Santos Silva analyses the political role of Isabel as a princess who 'received exactly the same rights and rents as her mother before her' (p. 198), giving her considerable power. This experience as a ruler early in her life probably helped Isabel to know how to gain and use authority when she became queen.

The following chapter, dealing with Blanca of Navarre, is archive-anchored and focuses on the reign of a fascinating princess who became queen of two realms: Sicily and Navarre - one through marriage and the other by birthright. Elena Woodacre is particularly interested in the connections that Blanca made through her marriage. The author also insists on the difficulties that Blanca had to face when being queen consort of Sicily (p. 211). According to Woodacre, Blanca endeavoured to demonstrate her political skills as queen consort, and this helped her assert her royal authority when she inherited the Navarrese throne. In the end, in marrying a Sicilian king and then securing the dynasty, Blanca acquired great connections for the Navarrese realm and played an important political role.

With a very engaging writing style, Fatima Rhorchi highlights the specificities of queenship in Morocco. Chapter 12 mainly focuses on Lalla Khnata Bint Bakkar who was 'an imposing female figure' (p. 230). From the story of her childhood and the importance of her background, the author also focuses on her marriage to 'one of the most powerful sultans of Morocco' (p. 232). When the sultan died, Rhorchi explains that Lalla Khnata still had to play 'several roles' (p. 236). She fought to preserve her alliances with different tribes, to maintain her authority, and finally to unify Morocco (p. 238). Supporting her son and later her grandson, Lalla Khnata proved to have a great impact on the history making of Moroccan realm. With this essay, Fatima Rhorchi sheds light on the great life and reign of a devoted queen who stayed too long in 'the shadow of the male character who took the centre of the stage' (p. 243).

The dynamic of royal couples has long been a source of fascination for historians.(2) The next chapter casts a light on an 18th-century royal couple's dynamic as well as responsibilities: Charles Emmanuel IV and his wife Marie Clotilde of France. The author shows that during challenging periods, the queen consort 'took over the reins of power' (p. 248) to help her husband and proved to be diplomatically and politically quite skilled. While queens usually seem to be remembered for their virtue and spiritual qualities, Feredica Contu is determined to demonstrate, through thorough and archival research, that Marie Clotilde of France actually played a political role, such as a minister might (p. 254) and for that reason deserves a growing interest.

Finally, the 14th and last chapter of this collection of essay focuses on the correspondence of a Naples queen to reveal new aspects of Maria Carolina of Naples' representation as well as the political role she once played as queen consort of Naples. Greatly influenced by her mother, Maria Carolina followed her advice and the two were indeed very close. Cinzia Recca also explains that Maria Carolina's husband and king was not interested in power (p. 267-8) which gave room for the queen consort to play her role as monarch 'dominating her husband, the court and ministers' (p. 268). With the consequences of the French revolution and Maria Carolina's political decisions, Ferdinand IV of Naples, her husband, managed to take control back of his realm and the queen consort was deprived of any sort of authority. Nevertheless, Maria Carolina will be remembered, thanks to the archival research of this essay and the revelations of her unedited letters, and despite what some would judge as failures on her part, as a politically involved and strong-minded queen 
consort.

With different queens, realms, and sources, this collection of essays manages to highlight the importance of female rulers in the Mediterranean and how queenship was as important in the southern sea as anywhere else in Europe. The chapters are engaging and fascinating, enabling the reader to develop an interest in each queen. Organising the collection chronologically is logical, although it would have also been possible to treat the topic thematically: queens regnant, then consorts, and then regents or geographically. The main strength of this collection is that it helps scholars, students, or anyone else interested in the topic to understand the specificities, paradox, and complexities of queenship and somehow to realise that it is, after all, not that different from kingship.

\section{Notes}

1. Jo Eldridge Carney, Fairy Tale Queens: Representations of Early Modern Queenship, (New York, NY, 2012), The Emblematic Queen: Extra-Literary Representations of Early Modern Queenship, edited by Debra Barrett-Graves, (New York, NY, 2013).Back to (1)

2. Elena Woodacre, The Queens Regnant of Navarre: Succession, Politics, and Partnership, 1274-1512, (New York, NY, 2013).Back to (2)

The author has no response, apart from to thank the reviewer for her kind and thoughtful review.

Source URL:https://reviews.history.ac.uk/review/1676

\section{Links}

[1] https://reviews.history.ac.uk/item/107141 